\title{
8
}
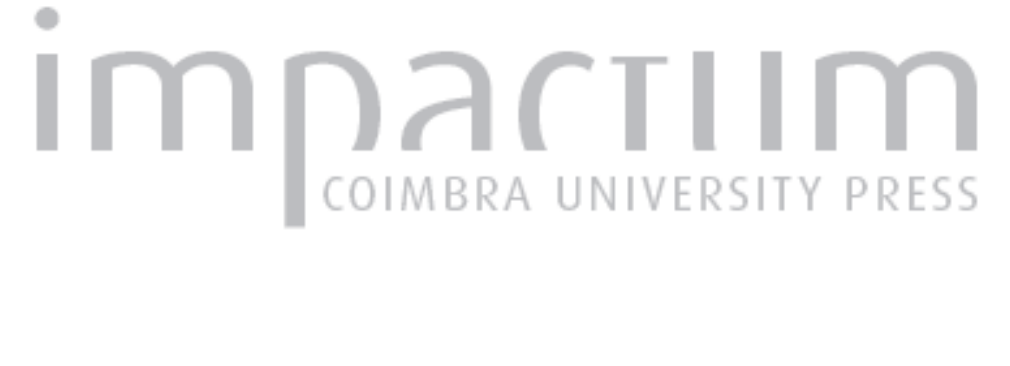
Medical anthropology, activists and intellectuals: an interview with Nancy Scheper-
Hughes
Autor(es):
Sousa, Liliana Gil
Publicado por: CIAS - Centro de Investigação em Antropologia e Saúde
URL
persistente:
URI:http://hdl.handle.net/10316.2/29602
DOI:
DOI:http://dx.doi.org/10.14195/2182-7982_29_13
Accessed : $\quad$ 26-Apr-2023 15:00:21

A navegação consulta e descarregamento dos títulos inseridos nas Bibliotecas Digitais UC Digitalis, UC Pombalina e UC Impactum, pressupõem a aceitação plena e sem reservas dos Termos e Condições de Uso destas Bibliotecas Digitais, disponíveis em https://digitalis.uc.pt/pt-pt/termos.

Conforme exposto nos referidos Termos e Condições de Uso, o descarregamento de títulos de acesso restrito requer uma licença válida de autorização devendo o utilizador aceder ao(s) documento(s) a partir de um endereço de IP da instituição detentora da supramencionada licença.

Ao utilizador é apenas permitido o descarregamento para uso pessoal, pelo que o emprego do(s) título(s) descarregado(s) para outro fim, designadamente comercial, carece de autorização do respetivo autor ou editor da obra.

Na medida em que todas as obras da UC Digitalis se encontram protegidas pelo Código do Direito de Autor e Direitos Conexos e demais legislação aplicável, toda a cópia, parcial ou total, deste documento, nos casos em que é legalmente admitida, deverá conter ou fazer-se acompanhar por este aviso.

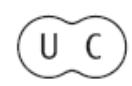




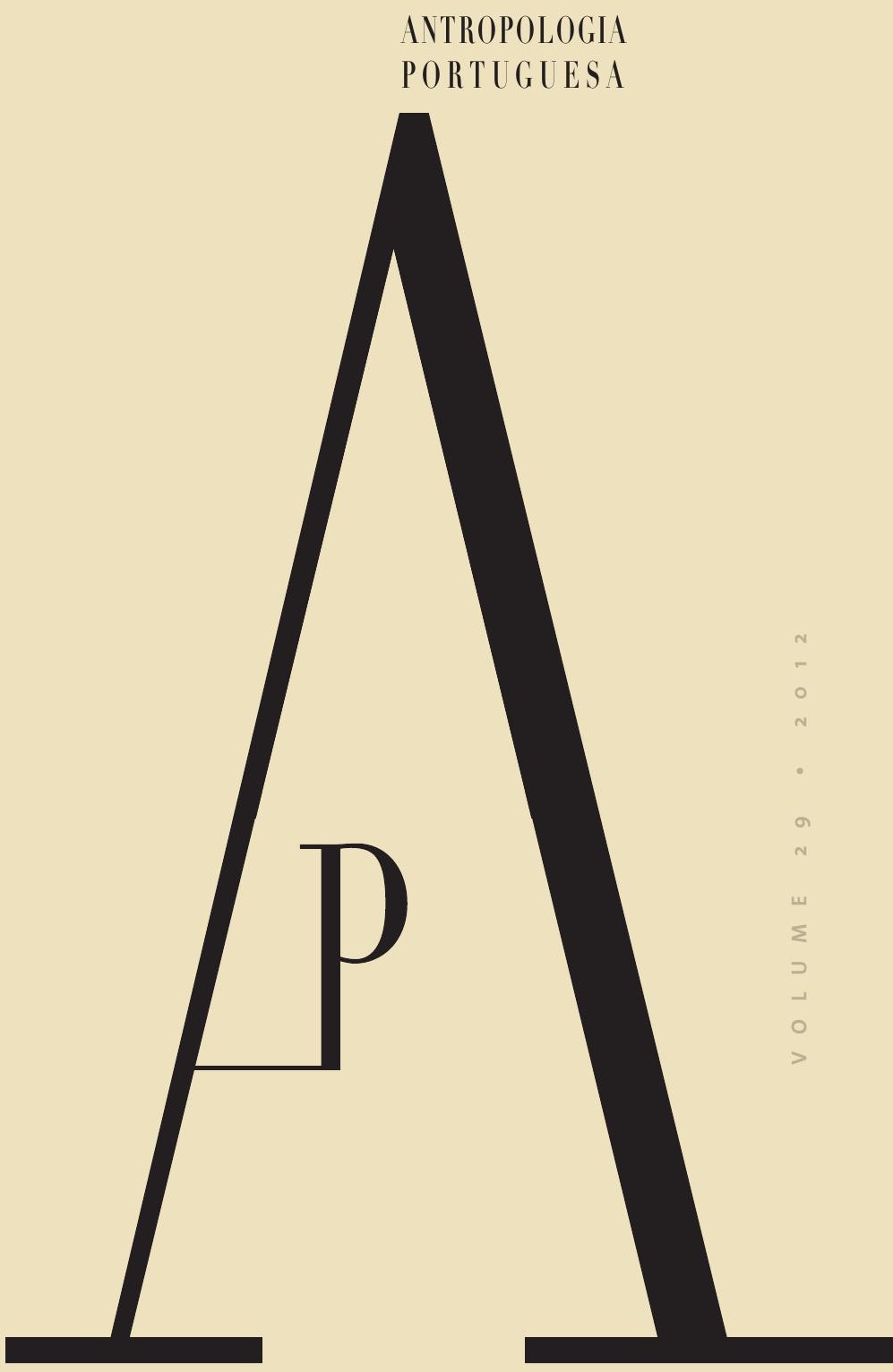

CENTRO DE

INVESTIGAÇ̃̃O

EI ANTROPOLOGIA

E SAÚDE

UNIVERSIDADE

DE COIMBRA 


\section{Medical anthropology, activists and intellectuals: an interview with Nancy Scheper-Hughes.'}

Nancy Scheper-Hughes (1944, New York City) is a Professor of Anthropology at UC Berkeley, Head of the UCB/UCSF Doctoral Program in Medical Anthropology and a contributor to the Critical Studies in Medicine, Science and the Body, at the same institution. As an anthropologist, she is mainly known for her richly ethnographically detailed work on various forms of human suffering, structural, symbolic and 'everyday' violence, theoretical concepts that are often confused or conflated (Scheper-Hughes and Bourgois, 2004). Nancy's engaged attitude toward fieldwork does not go unnoticed in her books. When I first thought of this interview, my intent was to explore this very same topic of engagement. But as soon as our conversation started, I knew that that was not even a question to be made. Nancy's commitment to ethnography as engaged witnessing was inherent to her practice, so we did not speak about medical anthropologists that are public intellectuals as opposed to the ones that are not. For one hour and a half, our conversation covered the failures and successes of Medical anthropology as an interdisciplinary project, the mediating role of the anthropologist, and the ethical challenges that many times run from it. For Nancy, understanding human difference may be the cornerstone of all anthropological work; however, despite the "suspension of disbelief" and of "bracketing" that the traditional stance of cultural relativism demands at the beginning of all new fieldwork ventures, this task does not exclude the application of ethical judgment and critical analysis, which should follow it. This is something Nancy has put into practice throughout her extensively discussed, praised, awarded and also challenged and critiqued work on Ireland, Brazil, and South Africa. Since 1997 Nancy has been involved in a multi-sited and hybrid research, documentation and medical human rights project on the global traffic

\footnotetext{
${ }^{1}$ Department of Anthropology, University of California, Berkeley, USA.
} 
in humans, dead and alive, for their organs and tissues (Scheper-Hughes, 2004; 2011). This work that has led her to collaborations with Ministries of Health, the UN Office on Human Trafficking, the Council of Europe, The Commercial Crime Branch of the South African Police, the Federal Bureau of Investigation, international transplant societies, and the World Health Organization. The following interview is a collection of excerpts on these topics that I selected from our conversation at her office in UCB on March 2011. I also tried to give a picture of the person Nancy is by asking her what experiences brought her to such a particular sensitivity and perspective on the relationship between knowledge and action.

A long time has passed since Saints, Scholars and Schizophrenics' publication (2001 [1979]), your first book. At that moment you introduced yourself as a "pathologist of the human condition", a position towards which you developed some "healthy skepticism", according to a later preface. This makes me think about the plurality of Medical anthropology as a field. Nowadays we have doctors, biologists and social scientists doing Medical anthropology that follow very different paradigms. In which ways is Medical anthropology a triumph and/or a failure of the interdisciplinary ideal?

I think interdisciplinarity is a great promise and a vision that we have always had. Anthropology itself is interdisciplinary. It's probably the last interdisciplinary discipline per se, that incorporates everything from the bio-evolutionary, the archaelogical, the ethno-historical, socio-cultural, the psychological, the political economic, the ecological, the epidemiological, to the folkloric. But the promise of interdisciplinarity always expires, always fails, always falls short. And in the end the best we can hope for is to try to understand each other's often incommensurate paradigms, to respect each other's methodological toolkits and to do whatever it is that we do best.

Medical anthropology emerged out of a kind of applied anthropology, which was founded on some version of improving the health and basic living conditions of people elsewhere. Initially Medical anthropology was not critical at all about the nature of its primary object - the human body as both historically and culturally constituted. In the United States after the end of World War II and the creation of the Marshall Plan for the reconstruction of war torn Europe, and in the new context of the cold war and the 'containment' of Communism world wide, North American cultural and applied anthropologists like George Foster at UC Berkeley and Ben Paul at Stanford University, among many others, were recruited to develop USAID and public health programs in developing nations. I think there was no real interdisciplinar- 
ity at that moment, it was really anthropologists serving the needs of global biomedicine, and serving as brokers between communities and state and international health care agencies. The role of the applied medical anthropologist was to 'educate the medically illiterate' to understand and accept the biomedical understanding of the body, disease and illnesss according to Western medical diagnoses and disease classifications. And that was a failure because culture, local knowledge, ethnoscience and alternative interpretations of the variety of human afflictions from which humans suffer, not to mention the role of political economy in the production of sickness and death - all of those things that go into understanding why people get sick and how they die - got collapsed into variables that would fit into large epidemiological public health type projects. So I have always seen the role of Medical anthropology to be epistemologically open, and acutely conscious of alternative perceptions of health and disease and to recognize that when it comes to biomedicine it's hegemonic, and anthropology is not and frankly can never be so. Medical anthropology is rarely even counter-hegemonic. It has made very little impact on how medicine is practiced, to be honest. The only things that biomedicine has taken or learned from Medical anthropology might be how to improve doctor-patient communication, with a view toward improving patient compliance, or perhaps to understand some of the obstacles to communitylevel acceptance of new kinds of treatments.

In Saints, Scholars and Schizophrenics I described myself as a pathologist of if not so much the human condition but of the small, human communities in which we work. I think that is still an accurate description of what we need to do. We are at the bed side of afflicted communities, afflicted bodies, and we need to diagnose them apart from and beyond biomedical classifications in order to understand what is really at stake, what is going on here. So there is something shamanic about what we do, I mean, it's like the Navajo hand trembler who says "let me see where in this body there are things that can help me to understand where your affliction comes from and how to deal with it". You know, the article I wrote on the three bodies, we are "hand trembling" over the body politic, over the social body, and over individual bodies to diagnose (anthropologically) where it hurts, how it hurts, who is afflicted with this and why (ScheperHughes and Lock, 1987). The best that the anthropologist can do is not to stick with the causes and what illnesses are, but really to show what it means to carry a burden of sickness and how that diagnosis itself is going to transform how you live in the world. 
Your distancing from Psychological anthropology's agenda appears to be a clear shift in the works subsequent to Saints, Scholars and Schizophrenics. Yet, one cannot fail to notice that you keep a very phenomenological orientation. From madness to child death, mother love, hunger, violence and organ transplanting, the dimension of people's experience is always present in your work. Is this concern something that arose from your first fieldwork experiences? Or is it previous to that?

I think you probably are trying to ask me whether if something foundational in my own life experience... Well, I was born in 1944 to an immigrant European family and, at the time, Williamsburg, New York City, was a very poor postWWII immigrant and refugee community and I was able to see people arriving, traumatized, from war-torn Europe. At that time Williamsburg was home to 10,000 Hasidic Jews, in addition to a new influx of Eastern Europeans, both Jewish and Catholic, and Puerto Ricans. I grew up with people that couldn't talk to each other. There were all of these differences in terms of how to make sense of what had just happened, you know, "how did this holocaust happen?". The word holocaust was not yet used. No one even had a word for the disaster. It was something that was a public secret, it was too soon to think about it but it was always there lurking in the background! When I was six or seven years old, or in the first grade or second grade of school, a classmate would come up to me and say "Your people killed my people"; and I would say "What are you talking about?". So, to use a language that I hate, it was a community suffering from extreme post-traumatic stress. You know, in the late forties, early fifties. And there were many many secrets that could not be spoken about - where you came from, who you were, even what your religion was... I think some of my concerns with what I have called "invisible genocides" (Scheper-Hughes, 1996) and with questions of violence (Scheper-Hughes and Bourgois, 2004) comes out of seeing the sadness of people who were relocated and who came to the U.S. and try to go forth with their lives. You began to question what kinds of people humans are, and their tendencies towards violence, towards scape-goating, and ostracism and exclusion to the point that you have people designated as less than human or better off dead, or even more better off that they had never been even conceived, or born.

I think my orientation to Anthropology came out of that background and certainly from my early engangements in Brazil as a Peace Corps Volunteer and then as a civil rights worker in Selma Alabama. But my orientation to the actual 
practice of anthropology came from my first mentor Hortense Powdermaker, who in her own lifetime was both an activist (in the U.S. labor movement in the 1930s) and a public anthropologist who believed that one could study a socalled primitive society, Lesu in Mealanesia, and return home to do a study of race relations in rural Mississipi and then go to Hollywood in the 1950s to study the power and politics of filmmaking. The sky was the limit! Hortense Powdermaker taught two classes that shaped my future in the field - Culture and Personality and Ethnographic Method. In Culture and Personality we examined the impact of colonization on the destruction of Native America and we studied the effects of the Holocaust on the survivors, many of whom were sitting in the classroom.

I guess what I've learned in all of these different contexts is the enormous capacity of people who are themselves victims to normalize and routinize and say "well, this is what life is!". One sees that power relations are internalized by the perpetrators of violence and equally accepted by the victims of violence. There is an enormous capacity of people who are in power of to ignore the consequences of what they're doing, to be good, as Hannah Arendt noted, 'good enough ordinary people', while at the same time as the authors of mass violence. By everyday violence
I generally mean bureaucratic violence. Violence that actually is carried out by "clerks" - that would be the term that I use, I often do. The low and middle level bureaucrats that can authorize the most horrible things in the name of normalcy, in the name of doing their job. When I talk about everyday violence I have in mind the coffin maker for the mayor of the place I called Bom Jesus de Mata (Scheper-Hughes, 1993). I spoke to the mayor and I said "you know, there are really horrendous rates of infant mortality in Alto de Cruzeiro", and Jacques Ferreira Lima, who was a good man, asked "Well, what shall we do?". And we started to talk about things and he said "let's meet again and talk about this". And in the next week, when I returned, he was smiling broadly and said "Nancy, I finally came up with a solution for this problem of infant mortality. I have hired a full-time carpenter who will dispense free coffins to every mother who needs them!". Now, that may seem totally absurd, I was stunned, but, you know, I didn't want to spoil his party, he was so happy that he had this. Here is the worst part: to this day, the people of the Alto de Cruzeiro from that generation say that the best thing that ever happened, the best Prefeito, the best mayor they had ever have was Jacques Ferreira Lima, because he gave everybody free coffins for their babies. 
From all the different sites that I have been in, it seems that the human does have an enormous capacity to live through horrible situations by those same defenses of normalization, seeing as it is ordinary, seeing as it is expected, seeing as it is a routine. How quickly can an abnormal situation be rendered in to something normal and livable? So it is also a sign - though obviously a dangerous one - of human resilience.

The sensibility towards human suffering is particularly apparent in your famous Death Without Weeping (1993). This reading was my first contact with your work, a requisite for an Anthropology of Human Rights course I took as an undergrad. I remember it to trigger a great debate in class around several hot issues you arise there. Among them, the proposal of "a more 'womanly' anthropology" still intrigues me. Can you comment on it a little bit? Which were the political statements caught up in those sentences? Do they still make sense in our days?

[laughs] Now that we have deconstructed gender, and we have so many different forms of feminism, right? I think I was using "womanly" in the sense that I would "maternal thinking and practice". You don't have to be biologically a woman to conform to some of the better aspects of womanly roles and behavior. There are, thank goodness, a great many womanly-hearted men! It used to be said that women had more fluid ego boundaries. Probably anybody who carries two, three, four or more beings inside them and then raise them would have fragile or flexible boundaries between self and other. But I don't believe you have to go through a birthing experience to tap into that ability, to identify, to empathize, to read people, to read emotions, to read bodies, or to not be necessarily word centered, which is especially important if you're working with people that don't have words, and there are many - they're called toddlers and infants, they're called people with extreme problems of articulation either because of madness or senility, or because of cognitive "deficiency"... I suppose I am referring to what Levinas would call "substitution". To me, the main role of the anthropologist is to be a tool of human reception, to use all of your senses. I mean, how many ethnographies use the sense of smell? Or even talk about it? Or heat, or color, the really sensual and sentient world that shapes peoples' experiences. My notion of a womanly anthropology was a kind of a boundary-less self, it's a confection, it's an artificial notion, but the idea that yourself is not so clearly bounded.

You know, I study "kidney hunters" and I found them to be human. I even "fell in love with them". Exactly. How else do 
you nod your head and say "oh my God, I see why you're doing it!". In the end, you come back and you get yourself back, retrieve your old self, but the womanly part is this idea of "can you get out of yourself? Can you be outside of your boundaries to almost invade the bodymind-soul of the other?". That's kind of what I meant. (...) Never forget the body. And not the body as a metaphor, not the body as a symbol of something else, but actually the body in itself, the real body, the embodied experience and how it carries all the traces: the traces of history, the traces of your family history, the traces of your cultural and political history. I always read class and power through the body. And I think maybe that's a more womanly anthropology. So some people might start from the top of understanding political economy and eventually looking at its effects on populations of bodies, or bio-power, or whatever; others start with the body right in front of you. That's how I start.

Your positioning seems to challenge the demands of objectivity and cultural relativism. To this critique, you answer that ethics is somehow "pre-cultural" and that anthropologists should not neglect their witnessing role. As witnesses of human affairs, anthropologists have the options of involvement and noninvolvement, both requiring ethical or moral judgment (Scheper-Hughes, 1995). But what do you mean by a pre-cultural ethics?

The idea that it was pre-cultural might have been influenced by Levinas, or Sartre, or whatever. But again, I think this came out of the womanly anthropology. When a woman actually gives birth, all in a sudden this creature comes out and cries, and it creates, pre-culturally, pre-verbally, a demand: a demand for face-to-face, (that's Levinas, of course!) a demand for care, a demand for reciprocity that has nothing to do with culture. It's pre-cultural in that sense. It's there. It's given. The human experience has certain moral demands that are there lying in wait already. Religion will tell you one thing, the law will tell you another, but it doesn't matter, it's something else. And I think also, to say that it's pre-cultural... well, back to the question where we were talking about paradigms that can't be corrected because you are inside of it, it's the same, you can always find a justification for witchcraft. The witchcraft among the Azande argument is perfect for this, because once you get caught up in your cultural view, so you can't judge it. Ethics has to stand outside of culture. But it's a dilemma: how do you stand outside your culture when you know what you know, you think what you think, you speak what you speak by virtue of language which is embedded in culture? Maybe it goes 
back to the attempt - even though if it's not possible - to stand outside culture in the sense that you're going to disbelieve (for the purpose of argument) your own culture. You have to be oppositional to your culture in order to judge it. It's even within the framework of your own, as well as trying to understand somebody else's. The whole point of ethnographic encounters and inter-subjectivity is stepping in, stepping out, stepping close, exchanging, empathy. But there is the pulling out again part which says: "Hey, wait a minute, these kidney hunters, part of them are making the argument on behalf of saving lives, but they don't see the effects that I see because I move between the kidney sellers, and the sellers after they go home, and what happens when they get back to their villages". Is it the ethnographic authority? Well, perhaps it is. We do have a profession, there are things that we can do better and things that we don't do so well, but the fact that we manage to take different positions and that we can do so by using our disciplined subjectivity - objectivity doesn't exist, just as what I'm calling a kind of radical dis-owning of your culture, doesn't exist. But there are ideal types and methodological ticks of the trade. Some people want to really go for data and evidence. And some other people - most of the cultural anthropologists, I would say - use their discipline subjectivity to try to access and understand the other, but it's limited, it's artificial, it's methodological relativism. Because in the end we still have to analyze it, because we have to put all the pieces together. You can't just take the view of the kidney broker, although every human being that we study deserves our respect as a human being and absolute loyalty to presenting their opinion as close to the bone as they presented it to you. But then, when you analyze, you have to keep the distance from it. So, you know, you can understand and explain and honor the people you're studying, but you don't have to say "therefore it's a good idea".

First as a Peace Corps' visitadora in Brazil, inspired by Paulo Freire's method of conscientização (é isso!), later as an author of non academic pamphlets and a collaborator with civic institutions, the maxim of bringing critical conscience to a wider public seems to be a constant in your life. I heard that you even cooperated with a FBI's investigation on organ trafficking, recently. How do you feel about what is and what should be the intellectual's social role?

I think that it isn't to translate things into a simple language - which sometimes is what people think being a public intellectual is - but rather to make 
issues public that were not public before. So, organs traffic did not exist in the public imagination, it was not on the radar and I spent a long time and a lot of travel trying to convince the transplant associations. I must have spoken to fifteen transplant societies in different countries. And to have it rejected. And it was not just because of me, or Organs Watch, but eventually, they began to see this was really a public issue. So to make things public, I think it is part of the role of the organic intellectual. I think the other part of it is the decisions you have to make, because the moral compass is difficult when you're working as I have. I mean, the reason I spoke to the FBI was not because I sought them out, not because I was paid by them - I was not a FBI informant - but I reported to the Commissioner of Health of New York City that there was organs trafficking that was in fact bringing in people from poor parts of Europe to serve as kidney sellers in hospitals in New York. And the Commissioner of Health said "this is international crime, this is department of justice stuff, this has nothing to do with us, you will have to talk with an FBI agent". I don't want to go down in the books being a FBI informant, I am very critical of what the $\mathrm{FBI}$ and the CIA and all those organizations have done. However, not all of the work they do is evil. I'm very careful with what I say, I never give the name of a person that hasn't been caught up as a recipient or as a buyer. It's very very tricky terrain to me. Sometimes it means that you're not pure, sometimes means that you do things that... but since I'm talkative and since I feel transparency is important, I'll say that I have done things that I am not sure they're right. But you do them because you hope it will make the trouble of going there and hearing all of those stories and gathering all that information worthwhile. What is it going to do? Is it going to sit in some academic book published by Duke University Press that undergraduate student read? [laughs] Nothing against my students, I love them! But, you know, I want to do a little more than that.

\section{Liliana Gil Sousa}

Centro em Rede de Investigação em Antropologia (CRIA), Portugal

Departamento de Ciências da Vida, Universidade de Coimbra, Portugal Faculdade de Ciências Sociais e Humanas, Universidade Nova de Lisboa, Portugal lilianagilsousa@gmail.com 


\section{Bibliographic references}

Scheper-Hughes, N. 1993. Death without weeping. The violence of everyday life in Brazil. Berkeley, University of California Press.

Scheper-Hughes, N. 1995. The Primacy of the Ethical: Propositions for a Militant Anthropology. Current Anthropology, 36(3): 409-440.

Scheper-Hughes, N. 1996. Small Wars and invisible genocides. Social Science and Medicine, 43(5): 889-900.

Scheper-Hughes, N. 2001 [1979]. Saints, Scholars and Schizophrenics. Mental Illness in Rural Ireland. Berkeley, University of California Press.

Scheper-Hughes, N. 2004. Parts unknown: Undercover ethnography of the organs-trafficking underworld. Ethnography, 5(1): 1-46.

Scheper-Hughes, N. 2011. Mr. Tati's Holiday and João's Safari - Seeing the World Through Transplant Tourism. Body \& Society, 17(2-3): 55-92.

Scheper-Hughes, N.; Bourgois, P. (eds.). 2004. Violence in war and peace: an anthology. London, Basil Blackwell.

Scheper-Hughes, N.; Lock, M. 1987. The mindful body: a prolegomenon to future work in Medical Anthropology. Medical Anthropology Quarterly, 1(1): 6-41. 